\title{
JAWNOŚĆ DZIAŁANIA WŁADZ PUBLICZNYCH JAKO DOBRO WSPÓLNE
}

\section{WPROWADZENIE}

Jawność informacji na temat funkcjonowania państwa i reprezentujących go funkcjonariuszy publicznych jest jednym z podstawowych wyznaczników istnienia realnego ustroju demokratycznego ${ }^{1}$. W sytuacji, w której mamy do czynienia z nieuzasadnionym limitowaniem takiego dostępu, a w szczególności z arbitralnym rozszerzaniem definiowania przez władze określonej sfery informacyjnej jako niejawnej, dochodzi do uprzedmiotowienia obywateli, których nie traktuje się jako realnych członków suwerena (Narodu) sprawujących władzę zwierzchnia, a jedynie jako zobowiązanych do realizacji nakazów i zakazów formułowanych odgórnie przez „organy rządzące”. Sytuacja taka prowadzi jednocześnie do zaprzeczenia możliwości funkcjonowania $\mathrm{w}$ takim państwie społeczeństwa obywatelskiego ${ }^{2}$, identyfikowanego ze wspólnota ${ }^{3}$, której członków łączy realizacja określonego celu", a jeszcze dokładniej ta-

${ }^{1} \mathrm{Na}$ temat nowego spojrzenia i podkreślenia roli obywateli w ramach różnego rodzaju procesów kontroli władzy zob. S. Wójcik, Demokracja i jej kryzysy. Czy partycypacja może być remedium?, w: M. Baranowski (red.), Demokracja i rola obywatela. O napięciu pomiędzy państwem, społeczeństwem i procesami globalizacyjnymi, Poznań 2014, s. 35 i n.

2 Jak podkreśla P. Gliński, „społeczeństwo obywatelskie, społeczeństwo aktywne, otwarte, demokratyczne, solidarne, wolne i odpowiedzialne zarazem [...]. Tylko taki partner jest w stanie kontrolować potężne struktury władzy politycznej i ekonomicznej oraz łagodzić skutki różnorakich napięć wewnętrznych w społeczeństwie. Tylko on potrafi wyzwolić społeczne rezerwy i obywatelską energię nawet w sytuacjach - wydawałoby się - beznadziejnych kryzysów społecznych i kulturowych", idem, Style działań organizacji pozarzadowych w Polsce. Grupy interesu czy pożytku publicznego, Warszawa 2006, s. 3. Na temat genezy tego pojęcia i jego specyfiki zob. M. Bartoszewicz, Społeczeństwo obywatelskie a pluralizm polityczny $i$ udziat obywateli $w$ życiu politycznym, w: M. Baranowski (red.), Prawna działalność instytucji społeczeństwa obywatelskiego, Wrocław 2009, s. 43 i n.; D. Pietrzyk-Revees, Idea społeczeństwa obywatelskiego. Wspótczesna debata i jej źródta, Toruń 2012, s. 17 i n.

${ }^{3}$ Jak podkreśla się w literaturze przedmiotu: „Praktyka działalności państwowej dowodzi, że jakkolwiek każda jednostka jako członek organizacji państwowej ma w systemie demokratycznym gwarantowane prawo udziału w działalności publicznej, to formy zbiorowej działalności sa najbardziej sprzyjające osiaganiu dobra wspólnego skorelowanego z interesem jednostek oraz sa najbardziej efektywne z zakresie uzyskiwanych rezultatów" - W.J. Wołpiuk, Naród jako pojęcie konstytucyjne, „Studia Iuridica Lublinensia” 2014, nr 22, s. 387.

${ }^{4}$ Jak się wskazuje, społeczeństwo takie może być definiowane dwojako: jako „przestrzeń działania instytucji, organizacji, grup społecznych i jednostek, rozciagająca się pomiędzy rodzina, państwem i rynkiem, w której ludzie podejmują wolną debatę na temat wartości składających się na wspólne dobro oraz dobrowolnie współdziałają ze sobą na rzecz realizacji wspólnych inte- 
kiego, których członkowie charakteryzują się „w dużym stopniu podzielana, zbiorową samoświadomościa - poznawczą i normatywną" Z Z tego też punktu widzenia największym zagrożeniem dla tak rozumianego społeczeństwa, jak również dla samej demokracji jest podejmowanie przez władze publiczne działań ${ }^{6}$ nakierowanych na wywołanie „obojętności i bierności obywateli”, oraz dyskredytowanie działalności demokratycznych instytucji i organów ${ }^{8}$.

Poszanowanie demokracji łaczące się ze stałym procesem wzmacniania procedur partycypacyjnych wymaga od władz realnego zagwarantowania dostępu do informacji, którego celem było, jest i będzie wzmacnianie stanu świadomości obywatelskiej. Tylko bowiem świadomy obywatel jest w stanie podjać merytoryczną i racjonalną decyzję, której skutki mają znaczenie nie tylko na płaszczyźnie kreowania składu konkretnych organów, w tym przede wszystkim organów przedstawicielskich, ale przede wszystkim w zakresie inicjowania różnego rodzaju procedur weryfikacyjnych służacych badaniu prawidłowości funkcjonowania wszystkich instytucji i mechanizmów w ramach demokratycznego państwa prawa ${ }^{9}$. Trwałym fundamentem demokracji - co wydaje się niezależne od stopnia zainteresowania udziałem obywateli w procedurach wyborczych - jest więc utrwalanie procedur dostępu do tej sfery informacji, która dotyczy działalności organów władzy oraz osób pełniących funkcje publiczne, a które to w państwie totalitarnym były w zasadzie niedostępne. Możliwość sprawowania rzeczywistej kontroli obywatelskiej, wykonywanej w związku z realizacją uprawnień informacyjnych, wzmocniona wolnościa prasy i innych środków przekazu, sama w sobie jest gwarancją demokracji.

resów”, oraz jako „społeczeństwo, w którym istnieją aktywni, myślący o interesach społeczności obywatele, zależności polityczne oparte na zasadach równości i stosunki społeczne polegające na zaufaniu i współpracy" - A. Krasnowolski, Spoteczeństwo obywatelskie i jego instytucje, w: Spoteczeństwo obywatelskie i jego instytucje, Kancelaria Senatu. Biuro Analiz i Dokumentacji, Opracowania tematyczne, OT-627, styczeń 2014, s. 5, z odwołaniem się do treści „Strategii wspierania społeczeństwa obywatelskiego na lata 2007-2013” przygotowanej przez Ministerstwo Pracy i Polityki Społecznej (2009).

${ }^{5}$ E. Shils, Co to jest społeczeństwo obywatelskie, w: K. Michalski (red.), Europa $i$ społeczeństwo obywatelskie, rozmowy $w$ Castel Gandolfo, Kraków 1994, s. 10; szeroko na temat koncepcji i pojęć zob. P. Ogrodziński, Pięć tekstów o społeczeństwie obywatelskim, Warszawa 1991, s. 7 i n.; K. Dziubka, Społeczeństwo obywatelskie: wybrane aspekty ewolucji pojęcia, Studia z Teorii Polityki, t. 2, Acta Universitatis Wratislaviensis No 2003, Wrocław 1998, s. 31-50.

${ }^{6}$ Oczywiście pozytywnie ocenić należy powołanie Pełnomocnika Rządu do spraw społeczeństwa obywatelskiego, choć w praktyce istotniejsze od wskazania kompetentnego urzędnika państwowego jest podejmowanie inicjatyw rzeczywiście służących wspieraniu działań i inicjatyw obywatelskich, zob. Rozporządzenia Rady Ministrów z 8 stycznia 2016 r., w sprawie ustanowienia Pełnomocnika Rządu do spraw społeczeństwa obywatelskiego, Dz. U. 2016, poz. 37.

${ }^{7}$ B. Geremek, Społeczeństwo obywatelskie i wspótczesność, w: Europa i społeczeństwo obywatelskie. Rozmowy w Castel Gandolfo, Kraków 1994, s. 248.

${ }^{8}$ H. Olszewski, O odchodzeniu od demokracji, „Państwo i Prawo” 2006, z. 8, s. 14-15.

${ }^{9}$ Zgodnie z treścią § 2 rozporządzenia w sprawie ustanowienia Pełnomocnika rządu do spraw społeczeństwa obywatelskiego do jego zadań należy przygotowanie narodowego programu rozwoju społeczeństwa obywatelskiego, monitorowanie wdrażania programu, koordynowanie i monitorowanie współpracy organów administracji rządowej z sektorem organizacji pozarządowych i innych instytucji obywatelskich. Więcej informacji na temat programu dostępne na stronie Pełnomocnika: <https://www.spoleczenstwoobywatelskie.gov.pl/narodowy-program-wspierania-rozwoju-spoleczenstwa-obywatelskiego> [dostęp: 29.12.2017]. 
Oczywiste jest przy tym, że żaden system, w tym również demokracja, nie jest doskonały. Dlatego również w ramach demokracji zdarzały się i będą się ujawniać pewne zjawiska, które negatywnie wpływać muszą na ocenę konkretnych procedur lub zachowania się funkcjonariuszy publicznych. W sytuacji, w której istnieja realne mechanizmy pozwalajace na wyegzekwowanie informacji ujawniających pewne odstępstwa od przyjętych reguł, jak również ich rozpowszechnienie i rozpoczęcie publicznej debaty, utrwala demokrację.

Z kryzysem demokracji będziemy mieli do czynienia wtedy, gdy tajność stanie się reguła, a nie ustawowo sprecyzowanym wyjątkiem, jak również dopiero wtedy, gdy pomimo ujawnionych nieprawidłowości istniejące instytucje prawne nie podejmą lub nie będą zdolne do podjęcia właściwych działań prowadzacych do wyciagnięcia stosownych konsekwencji prawnych, politycznych oraz społecznych.

Wreszcie z kryzysem takim będziemy mierzyli się również wtedy, gdy standardem stanie się przyjęcie przez rządzących, że jednostka ma zawsze służyć państwu w zakresie, w jakim jest to niezbędne do realizacji instrumentalnie przyjętych przez nich celów. Przedmiotowe i arbitralne traktowanie jednostki jako ,środka” umożliwiającego osiagnięcie zamierzonego rezultatu bez jednoczesnego respektowania gwarantowanych jej konstytucyjnie wolności i praw będzie równoznaczne z istnieniem jedynie pozornej demokracji.

\section{SPRAWOWANIE WEADZY W PAŃSTWIE DEMOKRATYCZNYM A KWESTIA POSZANOWANIA DOBRA WSPÓLNEGO}

Zgodnie z treścią art. 4 Konstytucji RP z 2 kwietnia 1997 r.: „Władza zwierzchnia w Rzeczypospolitej Polskiej należy do Narodu, który sprawuje ja przez swoich przedstawicieli lub bezpośrednio"10. Według Wiesława Kraluka przyjęcie w Konstytucji postanowienia, że władza należy do Narodu, stanowi podkreślenie „permanentnego charakteru owego zwierzchnictwa Narodu. Suwerenność Narodu tym samym trwa cały czas i nie wyczerpuje się w całości w demokratycznym akcie wyborczym, co można by wywodzić z ewentualnego zapisu o pochodzeniu władzy od Narodu"11. Jak łatwo też zauważyć, przyjęcie takiej koncepcji jest równoznaczne z tym, że potwierdza się możliwość spra-

${ }^{10} \mathrm{O}$ znaczeniu i zakresie pojęcia suwerennej władzy państwowej do czasu uchwalenia Konstytucji RP z 2 kwietnia 1997 r. zob. M. Gulczyński, Zasada zwierzchnictwa narodu, w: W. Sokolewicza (red.), Zasady podstawowe Polskiej Konstytucji, Warszawa 1998, s. 106-117 i cytowana tam literatura. Pomimo wielu koncepcji dotyczących pojęcia narodu, ustrojodawcy zazwyczaj chodzi albo o etniczne, albo polityczne jego określenie - zob. W. Zakrzewski, Pojęcie narodu w Konstytucji Marcowej, „Państwo i Prawo” 1946, z. 5-6, s. 46 i n.; zob. też: A. Ławniczak, Ewolucja pojęcia „naród” w polskich konstytucjach, Acta Universitatis Wratislaviensis 1992, Prawo CC, s. 141-145. O znaczeniu treści art. 4 zob. szerzej: K. Działocha, Komentarz do art. 4 Konstytucji, w: L. Garlicki (red.), Konstytucja Rzeczypospolitej Polskiej. Komentarz, t. 5, Warszawa 2007; t. 1: Komentarz do art. 1-86, red. M. Safjan, Warszawa 2016.

11 W. Kraluk, O rozumieniu i regulacji normatywnej demokracji bezpośredniej w nowej Konstytucji, „Gdańskie Studia Prawnicze” 3, 1998, s. 24. 
wowania władzy bezpośrednio przez Naród, który pozostając umocowany do działania władczego, może je realizować we wszelkich dostępnych formach. Przy istnieniu takiej konstrukcji konieczne jest jednak konstytucyjne zagwarantowanie możliwości realizacji owego zwierzchnictwa w drodze odpowiednich procedur. Samo bowiem wyrażenie w konstytucji zasady zwierzchnictwa narodu nie może być identyfikowane $\mathrm{z}$ istnieniem bezpośredniego udziału zbiorowego suwerena w sprawowaniu władzy.

Nie budzi wątpliwości, że w treści art. 4 Konstytucji została zdefiniowana jedynie pewna uniwersalna formuła ${ }^{12}$, której realne znaczenie ustala się $\mathrm{w}$ drodze dalszej konstytucyjnej konkretyzacji instytucji i procedur konkretyzujących, kto ze zbiorowego podmiotu składającego się na pojęcie suwerena ${ }^{13}$ uczestniczy w sprawowaniu władzy (przedstawicielskiej - parlamentarnej oraz bezpośredniej - np. wybory, referendum), jak również pozwala na rozgraniczenie idealnego i politycznego pojęcia Narodu, „,zyli uprawnionych i korzystających z uprawnień" ${ }^{4}$.

Z formuły tej wynika kilka istotnych wniosków dotyczących skutków sprawowania władzy zarówno za pośrednictwem przedstawicieli, jak i bezpośrednio. Po pierwsze, podstawowym elementem ograniczajacym samego suwerena jest wymóg istnienia procedur umożliwiajacych podejmowanie konkretnych rozstrzygnięć. Ich przestrzeganie oznacza spełnienie podstawowej przesłanki charakteryzującej istnienie demokratycznego systemu opierajacego się na szacunku dla prawa i zasady praworządności. Procedury te określone są w treści konstytucji, a w związku z tym odstępstwo od nich możliwe jest dopiero wtedy, gdy dojdzie do jej zmiany i ukształtowania nowych mechanizmów służących podejmowaniu decyzji ${ }^{15}$.

Po drugie, skutki podejmowanych rozstrzygnięć nie mogą naruszać postanowień konstytucji tak w aspekcie jej przepisów ustrojowych, materialnych i proceduralnych. Konstytucja jako najwyższy wyraz woli samego suwerena staje się więc ostateczną formalną gwarancją nie tylko tego, że państwo i jego organy działać będą na podstawie i w granicach prawa, ale również dla sa-

12 Według L. Garlickiego „w żadnym razie nie można utożsamiać Narodu z ogółem osób narodowości polskiej, a pozostawiać poza zakresem tego pojęcia osoby innej narodowości” - idem, Polskie prawo konstytucyjne. Zarys wykładu, Warszawa 1997, s. 53.

13 Dla jego zidentyfikowania często odwołuje się do treści Preambuły „Naród Polski - wszyscy obywatele Rzeczypospolitej”.

${ }^{14}$ M. Pietrzak, Demokracja reprezentacyjna i bezpośrednia $w$ Konstytucji RP, w: M.T. Staszewski (red.), Referendum konstytucyjne w Polsce, Warszawa 1997, s. 25; zob. też: M. Gulczyński, op. cit., s. 110 .

15 Jak podkreśla się w literaturze przedmiotu: „Naród sprawuje władzę nie dlatego, że tak stanowi konstytucja, ale dlatego, że tę konstytucję - działając przez swoich przedstawicieli, ale i bezpośrednio - współtworzył i zaakceptował. Tym samym jednak jednocześnie Naród pozostający niezmiennie piastunem władzy zwierzchniej - związał się normami konstytucji i zobowiązał się wykonywać ją na podstawie i w granicach konstytucji” - A. Rakowska-Trela, Zasada suwerenności narodu a zasada państwa prawa. Między harmonia a konfliktem, s. 105, opracowanie zamieszczone na: <http://dspace.uni.lodz.pl/xmlui/bitstream/handle/11 089/22964/\%5B101\%5D-110_Rakowska-Trela_Zasada\%20suwerenno\%C5\%9Bci\%20narodu. pdf? sequence=1\&isAllowed=y $>$ [dostęp: 29.12. 2017]. 
mego bezpośrednio działającego suwerena, który wyrażając swą wolę, musi przestrzegać tych zasad, które sam wcześniej ustanowił.

Oczywiście członkowie Narodu, przekazując swoje umocowanie, robia to w przeświadczeniu, że ten, kogo wybrali, będzie działał nie w celu realizacji interesów partykularnych, ale w imieniu całego Narodu. Pamiętać przecież trzeba, że obywatele jednocześnie zrzekają się możliwości wpływania na procesy prawotwórcze i nie maja prawnych środków oddziaływania w przypadku podejmowania działań sprzecznych z ich wolą. Gwarantem realizacji woli narodu i z drugiej strony podstawą funkcjonowania systemu reprezentacyjnego ma być dążenie do poszanowania przez reprezentantów dobra wspólnego ${ }^{16}$ będącego wyznacznikiem ich działania ${ }^{17}$, uznanego za wartość istniejąca obiektywnie, niezależnie od aktualnie wyrażanej opinii publicznej bądź tė̇ partykularnych interesów politycznych. Tym samym decyzje podejmowane przez organ przedstawicielski mają mieć w założeniu charakter realizujący to dobro, także wtedy, gdy spotyka się to z niezadowoleniem społecznym. Jeżeli jednak chcielibyśmy określić, jakie znaczenie ma pojęcie dobra wspólnego, powstałyby pewne problemy.

Z dotychczasowych ustaleń Trybunału Konstytucyjnego wynika, że istnieje możliwość przedłożenia w razie potrzeby dobra ogólnego ponad dobro indywidualne lub partykularny interes grupowy. Generalnie interpretacja tego pojęcia sprowadza się zaś do uznania, że wszyscy obywatele „są w stopniu odpowiednim do swoich możliwości zobowiąani do poświęcania pewnych interesów własnych dla dobra wspólnego". Dlatego też interes jednostkowy, nawet najlepiej pojmowany i w pełni znajdujaccy oparcie w przepisach obowiązującej Konstytucji będzie musiał ustapić przed koniecznością uwzględnienia dobra wspólnego $^{18}$. Wydaje się, że zasada ta przede wszystkim powinna dotyczyć członków organu przedstawicielskiego, którzy tworząc prawo, będą dążyli do podejmowania takich rozstrzygnięć, a te zaś nie będą identyfikowane z realizacją partykularnych interesów (np. partyjnych) ${ }^{19}$.

Oczywiście sposób rozumienia pojęcia dobra wspólnego jest zdecydowanie szerszy i nie może być ograniczany do rozumienia wypracowanego w orzecznic-

${ }^{16}$ Zgodnie z treścią art. 1 Konstytucji RP: „Rzeczpospolita Polska jest dobrem wspólnym wszystkich obywateli” - Konstytucja RP uchwalona przez Zgromadzenie Narodowe w dniu 2 kwietnia 1997 r., Dz. U. 1997, Nr 78 poz. 483 ze zm.

17 Por. wypowiedź prof. P. Winczorka, w: Biuletyn Komisji Konstytucyjnej Zgromadzenia Narodowego, nr VIII, Wydawnictwo Sejmowe, Warszawa 1994, s. 64; zob. także: W. Osiatyński, Demokracja a prawa człowieka, w: A. Rzepliński (red.), Prawa człowieka w społeczeństwie obywatelskim, Warszawa 1993, s. 43-44; A. Malinowski, Społeczne uwarunkowania referendum, w: M.T. Staszewski, D. Waniek (red.), Referendum w Polsce i Europie Wschodniej, Warszawa 1996, s. 79-81.

${ }^{18} \mathrm{Z}$ uzasadnienia wyroku TK z 12 kwietnia 2000 r., K 8/98; por. też wyroki TK z 16 lutego 1999 r., SK 11/98, i z 9 lutego 1999 r., U 4/98.

19 „Dobro wspólne zabezpieczane jest przede wszystkim przez odpowiednie organy państwa, w tym też organy uprawnione do stanowienia prawa. Organy te - w określonych sytuacjach - jeżeli tego wymaga ochrona dobra wspólnego, nie tylko moga, ale i mają obowiązek wprowadzenia ograniczeń w korzystaniu z wolności, jeżeli jest to konieczne dla takiej ochrony" - zdanie odrębne sędziego Mariana Zdyba do orzeczenia TK z 3 października 2001 r., K. 28/01. 
twie Trybunału Konstytucyjnego ${ }^{20}$. Uwage na to zwraca w swym kompleksowym opracowaniu Marek Piechowiak ${ }^{21}$.

Odwołując się ponadto do poglądów Anny Młynarskiej-Sobaczewskiej, można wskazać, że odwołanie się do dobra wspólnego służyć ma „legitymizacji działania władzy publicznej, wskazuje jej integracyjna rolę. Kategoria ta oznaczać powinna granice działania władzy i usprawiedliwienie działań władczych, dokonywanych właśnie dla dobra wspólnego, zdefiniowanego jako zespół warunków i okoliczności służących rozwojowi i życiu jednostek"22, a także - jak podkreśla to Marek Zubik - „osiagnięciu doskonałości przez jednostkę i ich wspólnoty"23.

W odniesieniu do form sprawowania władzy w państwie współczesnym musimy mieć świadomość, że uprawnionym do bezpośredniego uczestnictwa w ramach konstytucyjnie i ustawowo sprecyzowanych procedur wyborczych na poziomie ogólnokrajowym jest wyłącznie obywatel polski, który najpóźniej w dniu wyborów (głosowania referendalnego) ukończył 18 lat. Ograniczenie to, uznane za standard charakteryzujący model definiowania uprawnionego do czynnego udziału w procedurach sprawowania władzy, w istotny sposób identyfikuje podmiotowo treść dobra wspólnego, do którego ustawodawca konstytucyjny odwołał się m.in. w art. 1 Konstytucji RP. W odniesieniu do znacznej części naszego społeczeństwa - obywateli polskich, którzy nie ukończyli 18 lat, jak również takich, którzy ten warunek spełnili, ale są np. ubezwłasnowolnieni ${ }^{24}$, przyjmujemy bowiem, że - jak to wskazano wyżej - dobro wspól-

${ }^{20}$ Warto podkreślić, że późniejsze orzecznictwo TK w istotny sposób rozwija formułe dobra wspólnego. W jednym ze swych rozstrzygnięć Trybunał stwierdził, że „Rzeczpospolita Polska będąca dobrem wspólnym wszystkich obywateli (art. 1 ustawy zasadniczej) to nie tylko i nie przede wszystkim organizacja państwowa (organy). Należy bowiem zauważyć, że ustawa zasadnicza różnicuje powyższe pojęcie i kategorię dobra państwa (por. art. 113 Konstytucji). Równie istotnym aspektem dobra wspólnego, którym jest Rzeczpospolita Polska, jest wymiar mentalny. W tym kontekście, zgodnie z treścią preambuły Konstytucji, na dobro wspólne składa się w szczególności również historia, kultura, tradycja czy poczucie wspólnoty ze wszystkimi rodakami" - zdanie odrębne sędziego TK Zbigniewa Cieślaka do wyroku TK z 20 kwietnia 2011 r., Kp 7/09; zob. też wyrok TK z 21 września 2015 r., K 28/13.

${ }^{21}$ M. Piechowiak, Dobro wspólne jako fundament polskiego porzqdku konstytucyjnego, Warszawa 2012, s. 36 i n.; zob. też powołana przez autora literatura dotycząca dobra wspólnego, s. 20, przyp. 1.

${ }_{22}$ A. Młynarska-Sobaczewska, Dobro wspólne jako kategoria normatywna, „Acta Universitatis Lodziensis Folia Iuridica” 69, 2009, s. 72. Jak wskazuje autorka: „dobro wspólne jawi się jako wartość podstawowa i pierwotna, która legitymizuje działalność prawodawcy, a także wszelkiej władzy - w końcu wywieranie wpływu na zachowanie i życie jednostki także musi być usprawiedliwione nie czym innym, jak tylko dobrem wspólnym. Jeśli przyjąć - przy założeniu dobrej woli i racjonalności prawodawcy - że także prawo jako akt władczy ma jeden ogólnie zakrojony cel, a tym najdalszym i najbardziej ogólnym celem jest zawsze dobro wspólne, to nie można wręcz przyjąć, że mogłoby być inaczej" - ibidem, s. 70. O normatywnych charakterze dobra wspólnego zob. W. Brzozowski, Konstytucyjna zasada dobra wspólnego, „Państwo i Prawo” 2006, z. 11, s. 18 i n.

${ }^{23}$ M. Zubik, Refleksje nad dobrem wspólnym jako pojęciem konstytucyjnym, w: Prawo a polityka, Warszawa 2007, s. 394, a także analiza orzecznictwa TK, s. 396-397.

${ }^{24}$ Warto podkreślić, że z punktu widzenia wykładni prezentowanej w orzecznictwie TK należy dokonać rekonstrukcji konstytucyjnego znaczenia instytucji ubezwłasnowolnienia. Jednocześnie TK wyraźnie podkreślił konieczność dokonania zmian w zakresie instytucji ubezwłasnowolnienia, odwołując się jednocześnie do praktyki innych państw, w których odchodzi się od 
ne staje się wyznacznikiem działania (konstruowania i podejmowania decyzji i rozstrzygnięć) konkretnej grupy wyłonionych w drodze wyborów przedstawicieli bądź jeżeli chodzi o instytucje demokracji bezpośredniej - świadomych wyborców ${ }^{25}$.

Funkcjonowanie społeczeństwa obywatelskiego, a w jego ramach świadomych jednostek, nie może być ograniczane w sensie podmiotowym wyłącznie do działań podejmowanych przez uprawnionych obywateli (wyborców), a w zakresie przedmiotowym do realizacji praw wyborczych, udziału w referendum, inicjowaniu innych instytucji demokracji bezpośredniej, czy też tworzeniu lub członkostwie w partii politycznej (lub innych formach zrzeszeń). Realizacja wskazanej kategorii wolności i praw politycznych nie wyczerpuje bowiem w żadnym razie dostępnych płaszczyzn aktywizacji społecznej i obywatelskiej nakierowanej na kreowanie współczesnych standardów relacji między państwem a jednostką (wspólnotą jednostek) ${ }^{26}$.

Dlatego też potrzeba współczesnego definiowania państwa szczególnie z punktu widzenia dobra wspólnego wymaga spojrzenia na inne mechanizmy i instytucje, które w praktyce umożliwiają jednostce oraz wspólnotom czynne zaangażowanie się $\mathrm{w}$ działalność propubliczną ${ }^{27}$. Uważam przy tym, że zasadnicze znaczenie ma kwestia rzeczywistego zagwarantowania realizacji tych praw i wolności, które składają się na tzw. status informacyjny jednostki. Przyjmuje jednocześnie, że fundamentalna gwarancją demokracji jest współcześnie zapewnienie każdemu zainteresowanemu możliwości pozyskania informacji i wiedzy na temat działalności państwa i jego organów, co łączyć się będzie z procesem definiowania, kiedy i w jakim zakresie jednostka może sama, jak i wspólnie z innymi zaangażować się w szereg czynności towarzyszacych owemu działaniu ${ }^{28}$.

sztywnego ograniczania wolności i praw podstawowych osób z niepełnosprawnością intelektualna lub psychiczna, zob. szerzej: wyrok TK z 7 marca 2007 r., K 28/05. Na temat ubezwłasnowolnienia oraz analizy systemowej zob. M. Zima-Parjaszewska, Ubezwłasnowolnienie w świetle Konstytucji RP oraz Konwencji o Prawach Osób z Niepetnosprawnościami, Polskie Towarzystwo Prawa Antydyskryminacyjnego, która stwierdza: „W świetle zachodzących zmian w sposobie postrzegania niepełnosprawności, po ogłoszeniu wyroków Trybunału Konstytucyjnego z dnia 7 marca oraz 6 listopada 2007 r., w świetle postanowień Konwencji oraz orzecznictwa ETPCz, nie jest możliwe stosowanie ubezwłasnowolnienia w stosunku do osób z niepełnosprawnością intelektualną oraz z zaburzeniami psychicznymi z zachowaniem konstytucyjnie przewidzianych przesłanek ingerencji w sferę wolności i praw jednostki”, opracowanie dostępne na: <www.ptpa.org.pl/public/>.

${ }_{25}$ P. Uziębło, Demokracja partycypacyjna, Gdańsk 2009, s. 39 i n.

${ }^{26}$ M. Jabłoński, Społeczeństwo obywatelskie a konstytucyjne prawo dostęu do informacji publicznej, w: E. Gdulewicz, H. Zięba-Załucka (red.), Dziesięć lat Konstytucji Rzeczypospolitej Polskiej, Rzeszów 2007, s. 89.

${ }^{27}$ Czyli w zakresie nawet szerszym niż w: J. Trzciński, Rzeczpospolita Polska dobrem wspólnym wszystkich obywateli, w: J. Góral, R. Hauser, J. Trzciński (red.), Sqdownictwo administracyjne gwarantem wolności i praw obywatelskich 1980-2005, Warszawa 2005, s. 455 i n., ale wpisujące się w zdefiniowane przez M. Piechowiaka rozumienia dobra jako „warunków życia społecznego umożliwiajacych i ułatwiających integralny rozwój [...] członków wspólnoty politycznej” (op. cit., s. 433), z jednoczesnym jednak podkreśleniem indywidualnie podmiotowego charakteru prawa dostępu do informacji publicznej.

${ }_{28}$ Por. P. Szustakiewicz, Istota pojęcia informacja publiczna, „Kontrola Państwowa” 2011, nr 4, s. 95-96. Zob. szerzej: M. Bernaczyk, P. Kuczma, Jawność działania władz publicznych jako 
W takim właśnie ujęciu, tzn. swoistej uniwersalizacji zakresu realizacji wolności i praw, zapewniajacej każdemu zdolność oddziaływania na zachodzące procesy decyzyjne, jest dowodem na pełną identyfikację dobra wspólnego jako wartości, mającej znaczenie nie tylko z punktu widzenia rządzących, ale przede wszystkim rządzonych, którzy uzyskują realną szansę uczestniczenia w szeregu procedurach partycypacyjnych, a ponadto uzyskuja faktyczna możliwość kontroli szeregu procesów decyzyjnych, które realizowane są przez sprawujących władzę, na każdym jej poziomie.

\section{ROLA I ZNACZENIE PRAWA DOSTĘPU DO INFORMACJI PUBLICZNEJ W PROCESIE KSZTALTOWANIA TREŚCI ZASADY JAWNOŚCI}

Na tle powyższych uwag należy podkreślić szczególną rolę Konstytucji RP z 2 kwietnia 1997 r., w której zagwarantowano podmiotowe prawo do uzyskania informacji o działalności organów władzy publicznej oraz osób pełniących funkcje publiczne (art. 61) ${ }^{29}$. W istocie prawo to tworzy nowa jakość państwa i stanowi podstawową gwarancję demokracji, zapewniając jednocześnie jednostce i obywatelskim wspólnotom możliwość współuczestniczenia w realizacji różnego rodzaju zadań publicznych, ale również wpływania, a nawet demokratycznego wymuszania na władzy szeregu „aktywnych zachowań”, nakierowanych na osiagnięcie dobra wspólnego determinujacego z punktu widzenia postanowień Konstytucji RP (art. 1) służebną rolę takiego państwa i podmiotowe traktowanie jednostki.

Jednocześnie prawo to determinuje rozumienie dobra wspólnego w tym sensie, że elementem składowym tego dobra musi być zasada jawności funkcjonowania państwa, która doznaje ograniczeń w ściśle określonych i zdefiniowanych wyraźnie (ustawowo) przypadkach. Jawność ta odniesiona do pojęcia życia publicznego będzie identyfikowana $\mathrm{z}$ istnieniem roszczenia dostępu do informacji publicznej przez każdego zainteresowanego, czyli dostępu do wiedzy o działalności istniejącego aparatu publicznego i reprezentującej go grupy

zasada ustroju Rzeczypospolitej Polskiej, w: B. Banaszak, M. Jabłoński (red.), Konieczne i pożadane zmiany Konstytucji RP z 2 kwietnia 1997 r., Wrocław 2010, s. 205 i n.; P. Fajgielski, Informacja $w$ administracji publicznej. Prawne aspekty gromadzenia, udostepniania $i$ ochrony, Wrocław 2007, s. 13-18.

${ }^{29}$ Nie mniejsze znaczenie ma prawo do informacji o stanie i ochronie środowiska art. 74 ust. 3 Konstytucji RP. Na ten temat zob. szerzej: L. Garlicki, Komentarz do art. 74 Konstytucji RP, w: Konstytucja Rzeczypospolitej Polskiej..., s. 4-5. Autor podkreśla, że prawo podmiotowe wynikające $\mathrm{z}$ tego przepisu ma charakter bardziej konkretny niż te wymienione w art. 54 ust. 1 i 61 Konstytucji. Warto jednak podkreślić, że chodzi tu o konkretyzację przedmiotową. W istocie treść tego prawa jest bardziej ogólna niż prawa wymienionego w art. 61 Konstytucji, zob. też: A. Szmyt, W sprawie interpretacji art. 61 Konstytucji RP z 2 kwietnia 1997 roku, „Przegląd Sejmowy" 1999, nr 6, s. 68.

${ }^{30}$ J. Ciapała, Konstytucyjna regulacja praw podmiotowych. Podstawowe konsekwencje dla ustawodawcy, w: idem, K. Flara-Gieruszyńska (red.), Prawa podmiotowe. Pojmowanie w naukach prawnych. Zbiór studiów, Szczecin 2006, s. 43. 
piastunów. Konieczne jest przy tym przyjęcie założenia, że jawność ta musi być rozumiana szeroko jako możliwość uzyskania dostępu do informacji o wszystkich przejawach aktywności (jej braku) w obszarze związanym z funkcjonowaniem określonych instytucji publicznych oraz reprezentujących je osób ${ }^{31}$.

Pełna identyfikacja prawa dostępu do informacji publicznej nie jest możliwa bez analizy postanowień ustawy o dostępie do informacji publicznej ${ }^{32}$. W praktyce dopiero od momentu wejścia jej w życie rozpoczą się powolny proces poszerzania sfery jawnej informacji o funkcjonowaniu państwa i jego funkcjonariuszy. Wcześniej pomimo kilku lat obowiązywania postanowień Konstytucji RP realizacja uprawnień informacyjnych jednostki napotykała daleko idace problemy ${ }^{33}$.

W zakresie niniejszego opracowania istotne staje się zwrócenie uwagi na kilka podstawowych kwestii. Po pierwsze, prawo to realizować może każdy (osoby fizyczne, prawne, jednostki organizacyjne nieposiadajace osobowości prawnej) bez konieczności wykazywania interesu prawnego lub faktycznego.

Po drugie, realizacja tego prawa ma dalece odformalizowana postać. W praktyce uznano, że nawet anonimowy elektroniczny wniosek, o ile zawiera zdefiniowanie przedmiotu oraz sposobu udostępnienia, powinien być przez zobowiązanego rozpatrzony, a gdy dotyczy informacji publicznej, informacja taka powinna zostać udostępniona. Za źródło tej informacji uznano:

- dokument urzędowy;

- inne dokumenty (tzw. materiały urzędowe) tworzące dokumentację określonej sprawy będacej przedmiotem rozstrzygania przez organ (podmiot) publiczny ${ }^{34}$. W tym zakresie przyjmowano, iż informacją taką będzie „każda wiadomość wytworzona przez szeroko rozumiane władze publiczne, a także inne podmioty, które tę władzę realizują bądź gospodarują mieniem komunalnym lub majątkiem Skarbu Państwa, w zakresie tych kompetencji. [...]"35, przy jednoczesnym zastrzeżeniu, iż informacja publiczna dotyczy sfery faktów ${ }^{36}$, a zakres dokumentów udostępnianych w trybie ustawy o dostępie do

${ }^{31} \mathrm{~W}$ tym zakresie możemy odwołać się też do jednego z orzeczeń Trybunału Konstytucyjnego z 11 maja 2007 r. (K 2/07), w którym uznano, że lustracja może służyć „nie tylko zasadzie jawności życia publicznego, przejrzystości systemu sprawowania władzy (art. 61 Konstytucji), ale także ochronie samej demokracji w Rzeczypospolitej Polskiej stanowiącej dobro wspólne wszystkich obywateli (art. 1 Konstytucji). Wiąże się bowiem z reguły z zapewnieniem obywatelom prawa do informacji o osobach pełniących funkcje publiczne oraz bezpieczeństwa państwa poprzez właściwy, także ze względu na kwalifikacje etyczne, dobór kadr do obsady funkcji, stanowisk i zawodów wymagających zaufania publicznego".

${ }^{32}$ Ustawa z 6 września 2001 r. o dostępie do informacji publicznej, t.jedn.: Dz. U. 2016, poz. 1764 ze zm.

${ }^{33}$ Szerzej na ten temat: M. Jabłoński, Udostęnienie informacji publicznej $w$ formie wgladu do dokumentu, Wrocław 2013.

${ }^{34} \mathrm{~Np}$. wyrok WSA w Warszawie z 3 stycznia 2011 r., II SAB/Wa 264/10; wyrok NSA z 18 września 2008 r., I OSK 315/08.

${ }_{35}$ Por. wyrok WSA w Warszawie z 22 czerwca 2007 r., II SAB/Wa 175/06; wyrok WSA w Warszawie z 7 maja 2007 r., II SA/Wa 130/07; wyrok NSA z 20 stycznia 2012 r., I OSK 2118/11.

${ }^{36}$ Informacja publiczna odnosi się jednak do faktów, a także stanów określonych zjawisk na dzień udzielenia odpowiedzi. Wniosek o jej udzielenie nie może być więc postulatem wszczęcia postępowania w jakiejś innej sprawie ani też nie może dotyczyć przyszłych działań organu. Informacja publiczna odnosi się bowiem do pewnych danych, a nie stanowi środka ich 
informacji publicznej obejmuje dokumenty bezpośrednio wytworzone przez zobowiązanego, jak i te, których używa „przy realizacji przewidzianych prawem zadań (także te, które tylko w części ich dotycza), nawet gdy nie pochodza wprost od nich" 37 . Informację publiczną stanowi więc każdy dokument, wykorzystywany przez organ „do zrealizowania powierzonych prawem zadań"

- sumę wszystkich informacji związanych z dokumentacją znajdująca się w posiadaniu zobowiązanego, czyli: wystapienia, oceny dokonywane „przez organy władzy publicznej, niezależnie, do jakiego podmiotu są one kierowane i jakiej sprawy dotyczą", a nawet fakty i zdarzenia towarzyszące działalności zobowiązanego ${ }^{39}$. Informację publiczną w takim ujęciu stanowi więc „treść dokumentów urzędowych, wystapień i ocen dokonywanych przez organy władzy publicznej, niezależnie, do jakiego podmiotu są one kierowane i jakiej sprawy dotyczą $[\ldots . .]^{40}$.

Wreszcie po trzecie, istotne stało się podkreślenie, iż dostęp taki ma co do zasady charakter bezpłatny. W aspekcie proceduralnym należy nadto zauważyć, iż udostępnianie informacji publicznej nie wyczerpuje się wyłącznie $\mathrm{w}$ drodze rozpatrzenia wniosku pisemnego zainteresowanego (co do zasady bez zbędnej zwłoki, nie później niż 14 dni od dnia wpłynięcia wniosku). Równie skuteczna może być procedura ustnego udostępnienia informacji, jak również żądania udostępnienia informacji o określonym stanie faktycznym dotyczącym sprawy publicznej bez konieczności realizacji dostępu do dokumentu urzędowego lub zbioru tych dokumentów.

Dlatego też szeroko identyfikowano sposób i formę pozyskania informacji, tzn. była to informacja:

- uzyskana w jakiejkolwiek formie (wglądu, kopii dokumentu, przesłania dokumentu w postaci pliku, zdjęcia skanu itd.), również za pośrednictwem bezpośredniej wypowiedzi osób wchodzących w skład organów publicznych lub osób uprawnionych lub zobowiązanych do reprezentacji takiego organu oraz pracowników zapewniających jego obsługę;

- zamieszczona w Biuletynie Informacji Publicznej ${ }^{41}$ centralnym repozytorium, a nawet w inny sposób upubliczniona i funkcjonująca w publicznym obrocie.

\footnotetext{
kwestionowania - wyrok WSA w Warszawie z 21 czerwca 2007 r., II SAB/Wa 17/07; zob. też: wyrok WSA w Warszawie z 10 stycznia 2007 r., II SA/Wa 1595/06; wyrok NSA z 12 grudnia 2006 r., I OSK 123/06; wyrok NSA z 14 czerwca 2012 r. I OSK 638/12. Zob. też: D. Fleszer, Problematyka dostępu do dokumentów urzędowych w jednostkach samorzadu terytorialnego na gruncie ustawy o dostepie do informacji publicznej, „Przegląd Prawa Publicznego” 2009, nr 12, s. 41 i n.

${ }^{37} \mathrm{~Np}$. wyrok WSA w Warszawie z 22 czerwca 2007 r., II SAB/Wa 175/06.

${ }^{38}$ Np. wyrok WSA w Warszawie z 21 czerwca 2007 r., II SAB/Wa 17/07.

39 Wyroki: WSA w Warszawie z 16 stycznia 2004 r., II SAB 364/03; WSA w Warszawie z 7 maja 2007 r., II SA/Wa 130/07; WSA w Warszawie z 16 lipca 2008 r., II SA/Wa 721/08; wyrok NSA z 27 stycznia 2012 r., I OSK 2130/11.

${ }^{40}$ Por.: wyrok NSA z 9 lutego 2007 r., I OSK 517/06; wyrok WSA w Warszawie z 22 czerwca 2007 r., II SAB/Wa 175/06; wyrok WSA w Warszawie z 7 maja 2007 r., II SA/Wa 130/07; wyrok WSA w Warszawie z 10 listopada 2010 r., II SAB/Wa 218/10.

${ }^{41}$ Rozporządzenie Ministra Spraw Wewnętrznych i Administracji z 18 stycznia 2007 r. w sprawie Biuletynu Informacji Publicznej, Dz. U. Nr 10, poz. 68 ze zm.
} 
Wskazane cechy obowiąujących w Polsce rozwiązań w zakresie realizacji prawa dostępu do informacji publicznej w istotny sposób wpłynęły na ukształtowanie się modelu transparentności działania władzy publicznej i jej funkcjonariuszy. Jej ograniczenie miało charakter wyjątkowy, uzależniony od konieczności wykazania zasadności wykazania przez zobowiązanego, że konkretna informacja objęta jej ochroną jako tajemnica ustawowa bądź ze względu na ochronę prywatności osoby fizycznej.

Mając na względzie wskazane wyżej rozwiązania, warto podkreślić, że realizacja prawa dostępu do informacji publicznej możliwa była w zasadzie przez każdego, także cudzoziemca, a nawet osobę, która nie dysponowała choćby ograniczoną zdolnością do czynności prawnych. Możliwe to było nie tylko ze względu na specyfikę bezwnioskowego pozyskiwania informacji (np. za pośrednictwem BIP-u), ale w wielu przypadkach ze względu na istniejace odformalizowanie procedury, w ramach której nie stosuje się wymogów określonych $\mathrm{w}$ Kodeksie postępowania administracyjnego, a więc nie bada się, czy istnieje po stronie korzystającego z prawa odpowiednia legitymacja (jednocześnie podkreślić trzeba, że na etapie rozpatrywania wniosku nie istnieje odrębna procedura weryfikacyjna, majacca na celu ustalenie, kim jest żądający).

Praktyka ostatnich kilkunastu miesięcy dostarcza nam dowodów istotnej zmiany w ocenie zakresu odformalizowania procedury dostępu do informacji publicznej. Po pierwsze, w postanowieniu Trybunału Konstytucyjnego z 2 grudnia 2015 r. (SK 36/14) doszło do jednoznacznego potwierdzenia, że legitymowanym, a więc uprawnionym do realizacji, a co za tym idzie, ochrony konstytucyjnego prawa dostępu do informacji publicznej (art. 61 Konstytucji RP) - na drodze wystapienia ze skargą konstytucyjna - jest wyłacznie osoba fizyczna, posiadająca zdolność procesowa, będąca jednocześnie obywatelem polskim. Prawa takiego pozbawione są osoby będące cudzoziemcami, jak również inne podmioty prawa, a więc osoby prawne, jak i inne jednostki organizacyjne osobowości takiej nieposiadające. Choć rozstrzygnięcie to w istocie nie ma znaczenia dla identyfikacji uprawnionego na gruncie ustawy o dostępie do informacji publicznej, to w praktyce wyłącza możliwość skutecznego działania przez wiele organizacji pozarządowych, które specjalizują się w pozyskiwaniu informacji publicznej, inicjując w następstwie pozyskania konkretnej informacji szereg działań kontrolnych.

Po drugie, sąd administracyjny uznał, że nie dysponuje zdolnością procesową w zakresie dochodzenia realizacji prawa dostępu do informacji publicznej osoba nieposiadajaca pełnej zdolności do czynności prawnych ${ }^{42}$. W praktyce oznacza to, że osoba nieposiadająca pełnej zdolności do czynności prawnych

${ }^{42}$ „Ujęte w art. 2 ust. 1 ustawy z dnia 6 września 2001 r. o dostępie do informacji publicznej (Dz. U. z 2016 r., poz. 1764) słowo »każdy« obejmuje m.in. wszystkie osoby fizyczne, w tym również mające ograniczoną zdolność do czynności prawnych; jednakowoż osoby należące do tej kategorii nie mogą realizować przyznanych im tą ustawą uprawnień samodzielnie, a wyłącznie działając poprzez ustawowych przedstawicieli. W konsekwencji czego, po myśli art. $26 \S 2$ ustawy z dnia 30 sierpnia 2002 r. Prawo o postępowaniu przed sądami administracyjnymi (Dz. U. z 2016 r., poz. 718 ze zm.), osobom tym nie służy zdolność procesowa $\mathrm{w}$ sprawach dotyczących tego przedmiotu" - postanowienie NSA z 21 marca 2017 r., I OSK 2500/16. 
nie będzie mogła skutecznie dochodzić prawa dostępu do informacji publicznej na drodze postępowania sądowoadministracyjnego.

Po trzecie wreszcie - co będzie miało najszersze zastosowanie - sąd administracyjny uznał, że dla złożenia prawidłowego wniosku o udostępnienie informacji publicznej konieczne jest zamieszczenie w jego treści „co najmniej imienia i nazwiska wnoszącego" ${ }^{43}$. Brak elementu składowego, jakim jest oznaczenie imienia i nazwiska (wniosek anonimowy), skutkuje tym, że gdy na wezwanie zobowiązanego autor wniosku nie dokona identyfikacji - nie będzie można zarzucić mu bezczynności, a w konsekwencji wnioskodawca nie będzie mógł skutecznie dochodzić swojego prawa. Odmiennie niż we wcześniejszych wyrokach, sądy uznaja, że wniosek, który nie zawiera identyfikacji nadawcy, nie pozwala na ustalenie tożsamości skarżącego z realizującym prawo dostępu do informacji publicznej ${ }^{44}$.

\section{KONKLUZJE}

Nie budzi wątpliwości, że podejmowane w ostatnich kilkunastu miesiącach rozstrzygnięcia organów władzy sądowniczej w istotny sposób ograniczają ukształtowany wcześniej model odformalizowanego standardu realizacji prawa dostępu do informacji publicznej. W konsekwencji musi dojść więc do istotnego limitowania możliwości realizacji tego prawa, szczególnie w odniesieniu do procedury wnioskowej, inicjowanej dotychczas przez szeroka grupę podmiotów. Ograniczenia te, choć niedeprecjonujące istoty konstytucyjnego

${ }^{43}$ „[S]karżący może zaskarżyć bezczynność organu jedynie dotycząca nierozpatrzenia jego wniosku, a nie wniosku złożonego do organu przez kogokolwiek. Musi zatem wykazać, że to on żądał od organu dokonania określonej czynności (udostępnienia informacji publicznej). Z treści art. $50 \S 1$ p.p.s.a. wynika bowiem, że uprawnionym do wniesienia skargi jest co do zasady jedynie ten podmiot, który ma w tym interes prawny, czyli - w przypadku skargi na bezczynność organu w przedmiocie udzielenia informacji publicznej - ten podmiot, którego wniosku organ nie rozpatruje w ustawowym terminie. Z art. 10 ust. 1 ustawy wynika, że informacja publiczna, która nie została udostępniona w Biuletynie Informacji Publicznej, jest udostępniania na wniosek. Wniosek strony inicjuje postępowanie, które zmierzać ma do udostępnienia informacji. Brak skutecznie wniesionego wniosku oznacza zatem, że podmiot zobowiązany nie ma podstaw do udostępnienia informacji. W konsekwencji przyjąć należy, że w sytuacji, gdy skarga na bezczynność zostaje złożona przez podmiot, który nie był nadawcą wniosku o udostępnienie informacji publicznej, to nie sposób uznać, że jest ona zasadna. Podmiot - niebędący nadawcą wniosku - nie ma bowiem legitymacji do zaskarżenia bezczynności organu w rozpatrzeniu wniosku, którego nie był nadawca, tj. którego nie złożył" - WSA w Szczecinie z 31 marca 2016 r., II SAB/Sz 25/16; por. WSA w Łodzi z 13 lipca 2016 r., II SAB/Łd 149/16; WSA w Gdańsku z 29 czerwca 2016 r., II SAB/Gd 60/16. Zob. też: D. Fray, Wniosek o udostepnienie informacji publicznej nie musi zawierać podpisu i zamieszczona tam wypowiedź G. Sibigi, <http://www.rp.pl/W-sadzie-i-urzedzie/307069896-Wniosek-o-udostepnienie-informacji-publicznej-nie-musi-zawierac-podpisu.html\#ap-1> [dostęp: 29.12.2017].

${ }_{44}$ Sądowej (por. np. wyroki WSA: w Szczecinie z 31 marca 2016 r., II SAB/Sz 25/16 - prawomocny; w Łodzi z 26 stycznia 2016 r., II SAB/Łd 205/15 - prawomocny; w Warszawie z 14 kwietnia 2016 r., VIII SAB/Wa 5/16 - prawomocne odwołujące się do obowiązku oznaczenia wnioskodawcy; w Łodzi z 13 lipca 2016 r., II SAB/Łd 149/16; z 13 lipca 2016 r., II SAB/Łd 132/16; z 24 czerwca 2016 r., II SAB/Łd 86/16 oraz z 22 czerwca 2016 r. II SAB/Łd 56/16; w Gdańsku z 29 czerwca 2016 r., II SAB/Gd 60/16). 
prawa dostępu do informacji publicznej, nie moga być - właśnie z punktu respektowania dobra wspólnego - ocenione pozytywnie. W praktyce bowiem prowadzić będą do znacznego osłabienia aktywności nie tylko organizacji i wspólnot obywatelskich, które pozbawione zostały skutecznej możliwości wystapienia ze skarga konstytucyjna zgodnie z art. 61 Konstytucji RP, ale również tych wszystkich, którzy nie są pełnoletnimi obywatelami polskimi, posiadającymi pełnię praw publicznych. Można odnieść wrażenie, że przy podejmowaniu tych rozstrzygnięć zwyciężyło przekonanie o konieczności poszanowania wąsko rozumianego dobra państwa, jego organów i funkcjonariuszy, a nie dobra wspólnego identyfikowanego również z dobrem każdej jednostki zainteresowanej zapewnieniem sprawnie, przejrzyście i praworządnie funkcjonującego państwa.

Trudno jednocześnie przypuszczać, że istotne zmiany przyniesie uchwalenie ustawy o jawności życia publicznego, która zastapić ma ustawę o dostępie do informacji publicznej. Zasadniczo pierwsza wersja projektu udostępniona na stronie rcl-u miała dla uprawnionego o wiele gorsze rozwiąania, aniżeli te istniejace obecnie ${ }^{45}$. Zmiany $\mathrm{w}$ kolejnych wersjach projektu pozwalaja jednak przypuszczać, że ostatecznie uchwalona ustawa, rozszerzając zakres transparentności władzy publicznej - szczególnie w odniesieniu do informacji o wydatkowaniu środków publicznych i gospodarowania majątkiem publicznym - w istotny sposób wzmocni gwarancję poszanowania prawa do uzyskania informacji na temat działalności państwa i jego funkcjonariuszy. Problem jednak tkwi nie tyle w zdefiniowaniu zakresu informacji publicznej, ile $\mathrm{w}$ zrozumieniu potrzeby zagwarantowania skutecznej realizacji tego prawa w jak najmniej sformalizowanych procedurach przez jak najszerszy krag zainteresowanych. Jawność musi stać się bowiem „odruchowym” następstwem wytworzenia przez władze publiczne określonej informacji, a nie następstwem groźby wystapienia przez uprawnionego na drogę sądową. Jawność jako dobro wspólne musi być w tym ujęciu identyfikowana jako konsekwencja służby wszelkich organów i instytucji publicznych oraz reprezentujących je funkcjonariuszy publicznych, pełnionej dla dobra tych wszystkich jednostek i ich wspólnot, które łącząc swoją egzystencję i działalność z państwem polskim, sa jednocześnie zainteresowane tym, aby państwo to funkcjonowało dobrze, praworządnie, szanujacc wolności i prawa wszystkich, którzy znajdują się pod jego władza, czyli władzą Rzeczypospolitej Polskiej.

prof. dr hab. Mariusz Jabtoński

Uniwersytet Wroctawski

45 Jak wskazuje się w uzasadnieniu projektu: „Głównym celem proponowanej ustawy jest wzmocnienie transparentności polskiego państwa. Zmiany proponowane przez inicjatora ustawy zakładają uporządkowanie obecnie istniejących przepisów, ale również wprowadzenie nowych, nieznanych dotąd w polskim prawie, rozwiązań. Ich wspólnym celem jest wzmocnienie przejrzystości zarządzania państwem i jego majątkiem. Dzięki przepisom proponowanym w poniższym projekcie wzmocniona zostanie kontrola władz, zarówno instytucjonalna, jak i społeczna”, <https://legislacja.rcl.gov.pl/projekt/12304351> [dostęp: 29.12.2017]. Można mieć pewne wątpliwości, co do tych celów, szczególnie jeżeli weźmiemy pod uwagę połączenie w jednym akcie tak odległych kwestii, jak dostęp do informacji publicznej i procedury antykorupcyjne. 


\section{TRANSPARENCY OF THE ACTIVITIES OF PUBLIC AUTHORITIES AS THE COMMON GOOD}

\section{Sum mary}

The analysis contained in this article focuses on the specificity of identifying public information and determining the manner of implementing this right in terms of defining the content of the principle of state transparency. The case law practice (decisions of the Constitutional Tribunal and administrative courts) concerning the identification of the right holder and the procedures for obtaining public information have been examined and evaluated. At the same time, an attempt was made to identify the content of the concept of the common good as used in Article 1 of the Constitution of the Republic of Poland whose one of constituent elements is transparency of state actions, state bodies and public officials. 